\title{
RESEARCH IN PARAMETERS OF WORKING PROCESS OF INTERFUSING IN BATCHER MIXER
}

\author{
Aleksandr Kolesnikov, Alexander Pastukhov, Nataliia Vodolazskaya, Alexan Minasyan \\ Belgorod State Agricultural University named after V. Gorin, Russia \\ a.c.kolesnikov@mail.ru,pastukhov_ag@mail.ru,vnv26@bk.ru, alikmun@yandex.ru
}

\begin{abstract}
The energy saving waste-free technology of receiving vegetable protein from sugar beet pulp is developed. The analysis of functioning of the machines and equipment of the offered technology is made. The constructive scheme of the experimental batcher mixer is submitted. Theoretical bases of work of a batcher mixer are explained and regularities of the process of interfusing of liquids which allow to make the analysis of its working process are theoretically investigated. On the basis of the theoretical analysis of the working process of interfusing of juice of pressed sugar beet pulp and solution of organic acids in a batcher mixer the mathematical description of the process in the form of the equations of a trajectory of driving of a stream of solution of organic acids at expiration from a nozzle of a mixing element is received. In the research of the working process of a batcher mixer analytical expression for determination of the value of the jet force arising at the expiration of solution of organic acids from a nozzle of a mixing element and dependence of efficiency of knot taking into account its design data of a batcher mixer are received. In the research of a required power dependences of values of the traveling speeds and resisting strengths arising in the course of rotation of a mixing element are installed on the drive of the mixer. On the basis of the conducted researches the effectiveness of development and introduction of the technology of a batcher mixer is confirmed.
\end{abstract}

Keywords: vegetable protein, pressed sugar beet pulp, a batcher mixer, parameters.

\section{Introduction}

Now in the world the deficiency of protein about 4.5 million tons is observed. It creates problems in farm animals' fattening operation. The existing sources of receiving vegetable protein cannot solve the developed problem, therefore researchers carry out continuous search of alternative sources of vegetable protein [1;2]. In the authors' opinion the waste of beet sugar production, in particular, sugar beet pulp and juice from the pressed sugar beet pulp [3] can be such source of protein. At the same time, uniformity of application and distribution of solution of organic acids in juice influences the process of receiving vegetable protein. The use of the batcher mixer for the dosed components in a stream provides this uniformity.

The work purpose - identification of regularities between the kinematic, power and process parameters during operation of the batcher mixer.

The object of the research - working process of the batcher mixer when mixing solution of organic acids and juice of the pressed sugar beet pulp.

The subject of the research - analytical description of interrelations of the kinematic, power and process parameters during operation of the batcher mixer.

\section{Materials and methods}

Many scientists were engaged in processing waste of beet sugar production, however, they considered the questions concerning only processing of pressed sugar beet pulp, and by-products were just utilized [4-6]. Ensuring wastelessness of processing sugar beet is implemented on the basis of an essentially new energy saving waste-free technology of receiving vegetable protein from sugar beet pulp (RU 2268611). The scheme of placement of the equipment is shown in Fig. 1. Feeder 2 gives crude sugar beet pulp with humidity $90 \ldots 95 \%$ from the diffusive element 3 of the sugar plant to the loading bunker of the expeller 1 . There it is pressed with division into the pressed sugar beet pulp and juice. Juice through the matrix openings and screw openings comes to capacities for coagulation 8 . The pressed sugar beet pulp with humidity $30 \ldots 40 \%$ goes for drying. Exhaust gases with the temperature of $170 \ldots 200^{\circ} \mathrm{C}$ are used as the heat carrier when drying. The dried-up pressed sugar beet pulp is applied to production of pectin [7-9].

Solution of organic acids is prepared in the mixer 7. It consists of $30 \ldots 35 \%$ of formic acid, $25 \ldots 30 \%$ of acetic acid, $15 \ldots 20 \%$ propionic and $5 \ldots 6 \%$ of other organic acids. These elements by the doser 5 from the capacity for storage 4 get in the mixer 7 . The flow of juice is directed via the camera of the batcher mixer 6 . It is mixed with $1 \%$ solution of organic acids. The received mix is 
directed to the tanks for coagulation 8 and through $2 \ldots 3$ days proteinaceous paste is received, which is dropped out as deposit and clarified liquid. The proteinaceous deposit is sent to the dryer. The clarified liquid is merged in the capacity 9 and used as additive in the diet of animals or for production of fodder yeast [10].

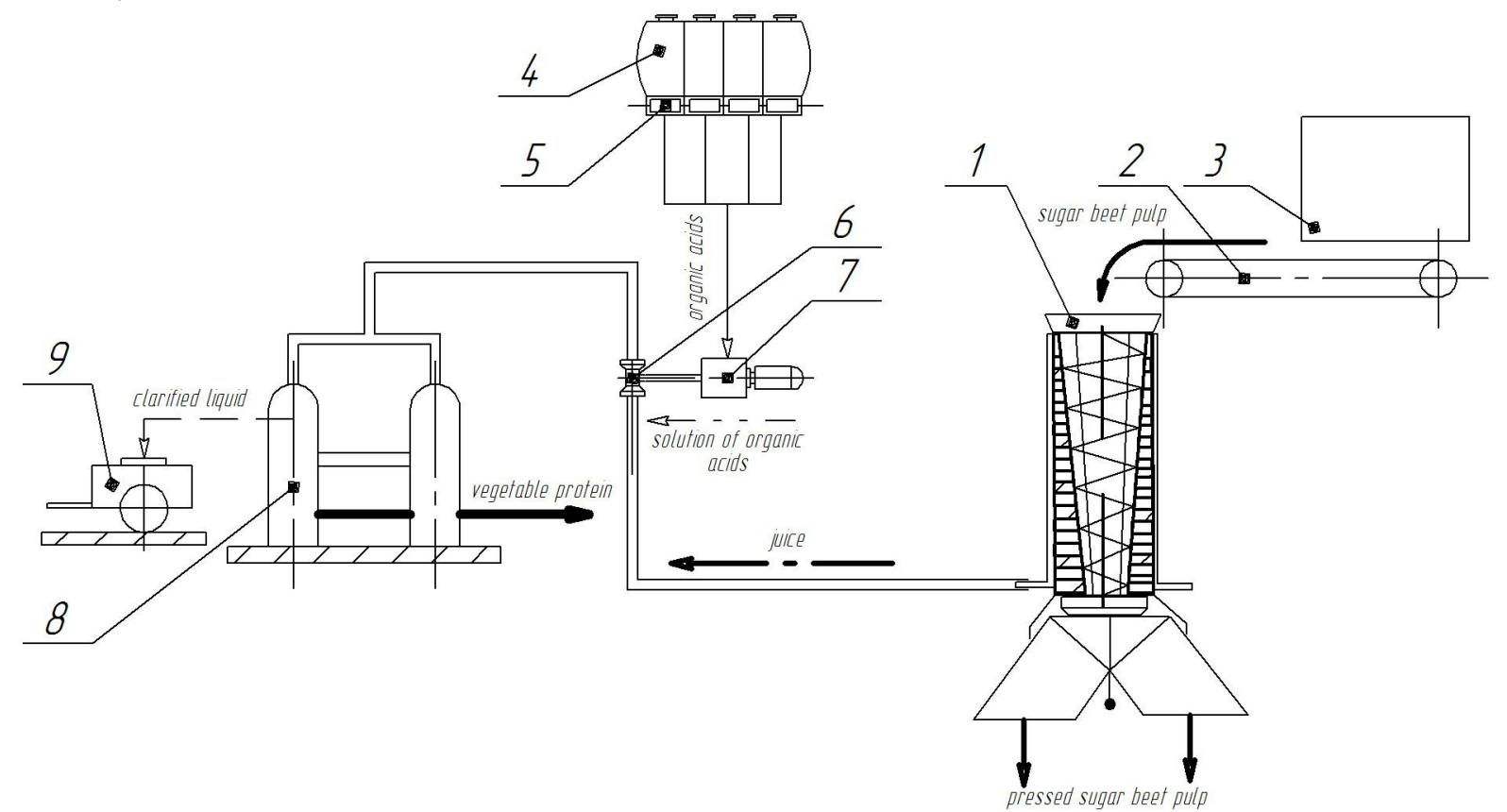

Fig. 1. Scheme of placement of equipment for receiving vegetable protein from sugar beet pulp

The efficiency of the process of mixing liquids is defined by the mixer design. The existing designs of mixers do not meet the requirements of the offered technology [11;12]. The mixer of liquids (RU 2250799) with the rotating mixing element and the portioning device is developed (Fig. 2) for the purpose of improvement of the quality of ready mix, improvement of hashing and ensuring dosing of components. The main flow of juice is given to the flowing camera of the case of the mixer 1. And at the same time solution of organic acids is given to the mixing element 2 along the pipeline 6 . The juice flow and the reactive force arising at the expiration of solution of organic acids bring the mixing element 2 into rotation. Then input of solution of organic acids occurs on all width of the flow of juice. The directing valve 3 carries out a diffuser role. At the same time dosing of the mixed components is carried out automatically through the system of the valves 4 and 7 connected by the mechanical draft 8 . The flow of juice is sent to the flowing camera of the building 1 from top to down. The valve 4 opens access of juice and it turns the lever 5 when the force of influence of the flow of juice exceeds rigidity of the return spring 10. Draft 8 turns the lever 9 . Lever 9 opens the valve 7 and it provides input of solution of organic acids. The valve 4 under the influence of the return spring 10 closes the channel of supply of juice when supply of juice is stopped. Then the system of levers 5, 9 and draft 8 close the valve 7 . This mixer is placed in the process pipeline. It provides stream-lining of production.

Let us consider the working process of the batcher mixer in terms of interrelation of the kinematic, power and constructive process parameters (Fig. 3).

The feedline flow rate through one opening is equal to $Q=\rho_{B} v_{B} S, \mathrm{~kg} \cdot \mathrm{s}^{-1}\left(v_{B}, \mathrm{~m} \cdot \mathrm{s}^{-1}-\right.$ speed of the movement of solution, $S, \mathrm{~mm}^{2}$ - the cross-sectional area). At the same time solution of organic acids is not squeezed. Therefore, its density $\rho_{B}, \mathrm{~kg} \cdot \mathrm{m}^{-3}$ is constant. Then the speed $v_{B}$ is identical in any section of the tube when $S$ is a constant. The tube by length $2 l, \mathrm{~m}$, gets the angular speed $\omega, \mathrm{s}^{-1}$, as a result of emission of solution of organic acids. The linear (surface) speed of its ends is equal to $\omega l, \mathrm{~m} \cdot \mathrm{s}^{-1}$. It is opposite to the speed $v_{B}$. The velocity of retreat is equal $v_{0}=v_{B}-\omega l, \mathrm{~m} \cdot \mathrm{s}^{-1}$. An impulse stream through one opening is $Q\left(v_{B}-\omega l\right)$, and its measure unit $-\left[\mathrm{kg} \cdot \mathrm{m} \cdot \mathrm{s}^{-2}\right] \equiv[\mathrm{N}]$, i.e. force $-F$. 


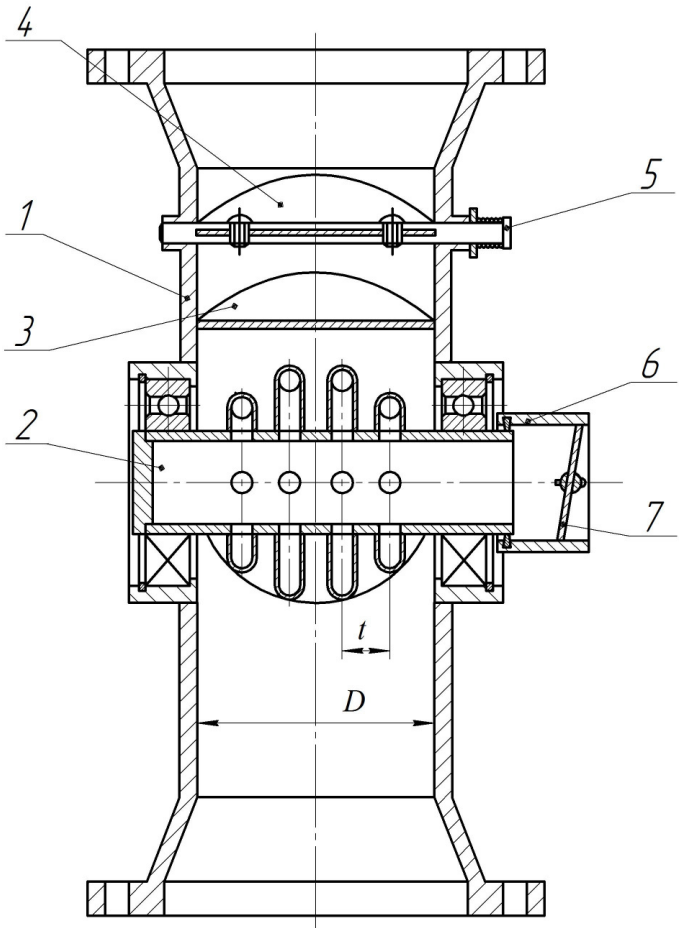

a)

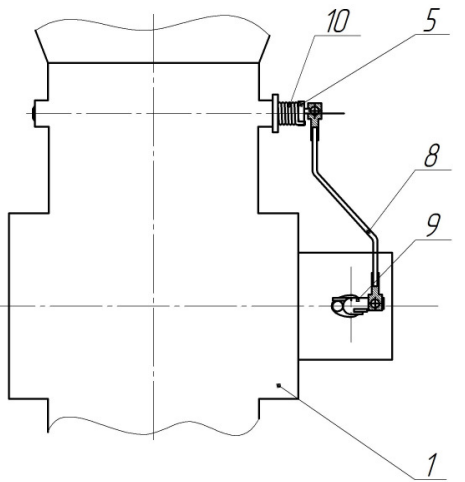

b)

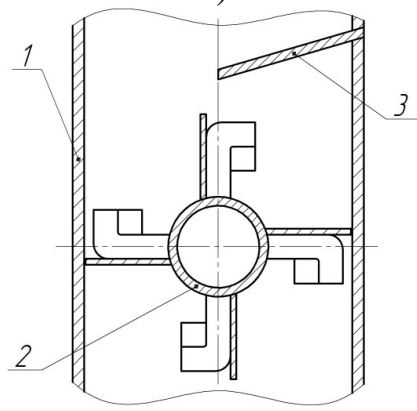

c)

Fig. 2. Batcher mixer: a - longitudinal section of the mixer;

$\mathrm{b}$ - general view of the mixer; $\mathrm{c}-$ mixing element

Thus, there are two pairs of forces - two forces are equal in size, parallel and opposite directed, and $l-$ an arm of each force concerning the rotation axis (Fig. 3). In this case for the tube the condition of balance of the described moments of forces is

$$
F \cdot 4 l=4 Q\left(v_{B}-\omega l\right) l .
$$

Let us equate the moment of the jet force (1) to the braking moment of the frictional force $M_{f}, \mathrm{Nm}$,

$$
4 Q\left(v_{B}-\omega l\right) l=M_{f},
$$

from where the velocity of retreat $v_{0}, \mathrm{~m} \cdot \mathrm{s}^{-1}$ of solution of organic acids from the nozzle

$$
v_{0}=v_{B}-\omega l=M_{f} / 4 l Q .
$$

The trajectory equation of the movement of solution

$$
x=-l \sin \alpha+v_{0} \cos \alpha \cdot t, y=h+l \cos \alpha+v_{0} \sin \alpha \cdot t-\left(g t^{2} / 2\right),
$$

where $t$-time from the moment of emission of elementary mass of solution from the tube, $\mathrm{s}$;

$v_{0}$ - initial speed;

$x_{0}=-l \sin \alpha, y_{0}=h+l \cos \alpha-$ coordinates of point;

$h$ - height of position of the center of the mixer, $\mathrm{m}$.

The stream following from the opening or the nozzle is characterized by the jet action. That needs to be considered in interaction with the environment (juice). Variation of momentum $|m v|_{\text {ex }}$ is [13]

$$
|m v|_{e x}=\rho Q v d t .
$$

Then $N d t=\rho Q v d t$, from where $N=\rho Q v$. Therefore, this jet force is $F_{R}=-\rho Q v$ (taking into account the third law of Newton).

At the expiration of juice from the opening the jet force $F_{R}, \mathrm{~N}$ is expressed by the equation [14]

$$
F_{R}=-2 \mu \varphi \gamma S H,
$$

where $\mu$-coefficient of the liquid expiration, it is recommended to accept $0.8 \ldots 0.9$; 
$\varphi$ - coefficient of supply of solution of organic acids depending on the design of nozzles and their arrangement on the shaft, it is recommended to accept $0.6 \ldots 0.8$;

$\gamma$ - specific weight of the liquid coming out from the nozzle, $\mathrm{kg} \cdot \mathrm{m}^{-2} \cdot \mathrm{s}^{-2}$;

$H$ - pressure, m.

When $\mu=0.62$ and $\varphi=0.97[14 ; 15], F_{R 0}=-1.2 \gamma S H$ is received and for the external cylindrical nozzle at $\mu=0.82$ and $\varphi=\mu-F_{R \mathrm{n}}=-1.346 \gamma \mathrm{SH}$.

Productivity of the batcher mixer $Q, \mathrm{~kg} \cdot \mathrm{h}^{-1}$ is determined by formula [14]

$$
Q=4 V_{c} \rho n_{\kappa} 60,
$$

where $V_{\mathrm{c}}$ - volume of solution of organic acids for one turn, $\mathrm{m}^{3}$;

$n_{\kappa}$ - rotating speed of the mixing element, $\min ^{-1}$.

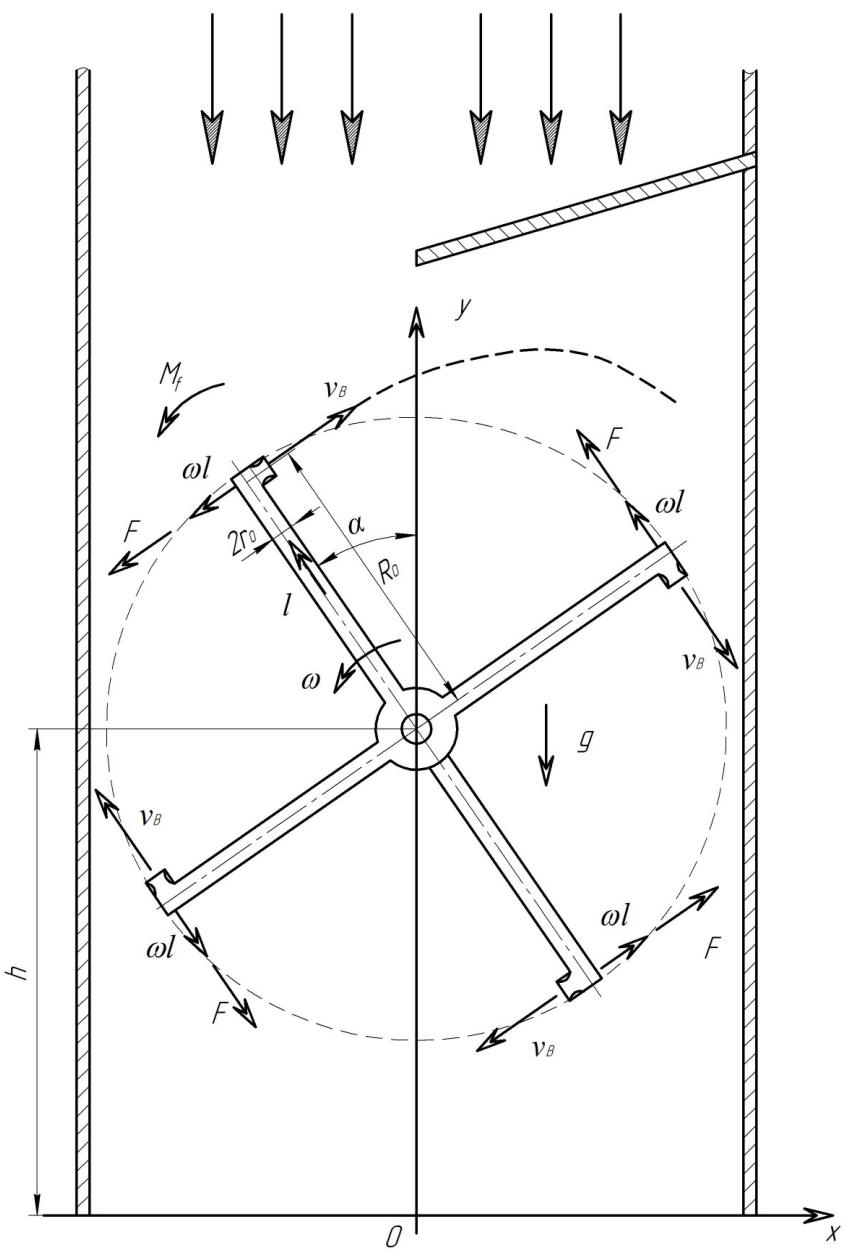

Fig. 3. Scheme for definition of movement trajectory of stream at expiration of solution of organic acids

In the course of operation of the doser with the known cross-sectional area of the exhaust outlet of the nozzle of round section the volume of solution for one turn $V_{\mathrm{c}}, \mathrm{m}^{3}$ is equal

$$
V_{c}=2 \pi R_{0} S,
$$

where $R_{0}$ - distance from the rotation axis to the center of gravity of the section, $\mathrm{m}$.

For geometrical reasons at the radius $R, \mathrm{~m}$, and the length of a nozzle $l$, m the distance of $R_{0}, \mathrm{~m}$, is determined by formula $R_{0}=\left(R^{2}+l^{2}\right)^{0.5}$.

Nozzle cross-sectional area $S$, at the known radius of the nozzle of $r_{0}$, m, is equal to $S=\pi r_{0}^{2}$, then on the basis of expressions for $V_{\mathrm{c}}, R_{0}, S$ from formula (7) it is

$$
Q=8 \pi^{2} r_{0}^{2} \sqrt{R^{2}+l^{2}} .
$$


In order to avoid self-outflow of solution of organic acids it is necessary:

$$
m R_{0} \omega_{\kappa}^{2} \leq m g f,
$$

where $m$ - mass of the liquid coming out from the nozzle, $\mathrm{kg}$;

$g$ - acceleration of gravity, $\mathrm{g}=9.81 \mathrm{~m} \cdot \mathrm{s}^{-2}$;

$f$ - friction coefficient of mix around the nozzle.

The left part of inequality (10) - the centrifugal force, and right - the friction force of particles of solution around the tube walls. Critical value of the angular speed

$$
\omega_{\kappa} \leq \sqrt{f g / R_{0}} .
$$

Productivity $Q, \mathrm{~kg} \cdot \mathrm{h}^{-1}$ of the liquid batcher, when mixing is equal [14]

$$
Q=\mu S v \rho \cdot 3600 \text {. }
$$

Velocity of retreat of solution, when mixing $v, \mathrm{~m} \cdot \mathrm{s}^{-1}$, is determined by formula

$$
v=\sqrt{2 g R_{0}} \text {. }
$$

Rotational speed of the mixing element is determined from a condition, under which the centrifugal force should be less or is equal to the material gravity $m \omega^{2} R_{0} \leq m g$, at the same time, the allowed angular speed of rotation of the impeller is defined from condition $m \omega^{2} R=m g$.

Having expressed the angular speed through therotating speed of an axis of the impeller $\omega=\pi n / 30$ and having solved the equation $n_{\max }, \min ^{-1}$, is received $n_{\max }=30 / \pi \sqrt{g / R_{0}} \approx 30 / \sqrt{R_{0}}$.

Then productivity of mixing of $Q, \mathrm{~kg} \cdot \mathrm{h}^{-1}$, is

$$
Q=60\left(\pi D^{2} / 4\right) \operatorname{tn} \rho \varphi=15 \pi D^{2} \operatorname{tn} \rho \varphi,
$$

where $D$ - diameter of throughway opening of the doser mixer's body, m;

$t$ - step of arrangement of nozzles on the mixing element, $\mathrm{m}$;

$n$ - rotating speed of the mixing element, $\min ^{-1}$;

$\rho$ - density of the mixed weight, $\mathrm{kg} \cdot \mathrm{m}^{-3}$.

Required power of $N_{\mathrm{n}}, \mathrm{kW}$ for the drive of the mixing element is determined by formula [14]

$$
N_{n}=\sum\left(P_{r} V_{r}+P_{a} V_{a}\right) / \eta,
$$

where $P_{r}$ - radial component of theforce of resistance to rotation, $\mathrm{N}$;

$V_{r}$ - district speed of the point of application of the net force, $\mathrm{m} \cdot \mathrm{s}^{-1}$;

$P_{a}$ - axial component of the force of wrung-out liquid operating on the nozzle, N;

$V_{a}$ - axial speed of the movement of the point of application of the net force, $\mathrm{m} \cdot \mathrm{s}^{-1}$;

$\eta$ - transfer efficiency.

District $V_{r}$ and axial $V_{a}$ speed

$$
V_{r}=(2 l \cos \theta+d) \omega ; V_{a}=V_{r} \cos \alpha \sin \alpha,
$$

where $\theta$ - nozzle angle of rotation, degree;

$d$-diameter of the nozzle, $\mathrm{m}$.

Radial $P_{r}$ and axial $P_{a}$ forces are determined by formulas

$$
P_{r}=9.81 \rho \operatorname{Stg}^{2}\left(45^{0}+\frac{\varphi_{f}}{2}\right)(\cos \alpha+f \sin \alpha) ; P_{a}=9.81 \rho h \operatorname{Stg}^{2}\left(45^{0}+\frac{\varphi_{f}}{2}\right)(\sin \alpha+f \cos \alpha),
$$

where $h$-depth of immersion of the nozzle, $\mathrm{m}$;

$\varphi_{f}-$ angle of friction of the nozzle around juice, degree.

The analysis of the given results shows that for the offered batcher mixer design the received analytical expressions demonstrate its productivity that will be coordinated with the data of researches of mixing devices $[11 ; 12]$. 


\section{Conclusions}

1. Analytical regularities of interrelations of the kinematic, power and process parameters during operation of the batcher mixer are received by consideration of interaction of the flow of juice with solution of organic acids moving the mixing element, which allows to set the device productivity.

2. Expression for determination of limiting frequency of rotation is set from a condition of restriction of outflow of organic acid solution from the mixing element, which determines the operation mode and the possibility of regulation of productivity of the batcher mixer.

3. Expression for determination of the required power on the drive of the mixing element is received in the research of analytical dependences of the speed values and resistance forces arising in the course of rotation of the mixing element.

\section{References}

[1] Iconomou D., Israilides C.J., Kandylis K., Nikokyris P. Protein enrichment of sugar beet pulp by solid state fermentation and its efficacy in animal feeding. Advances in Solid State Fermentation. 1997, pp. 289-298.

[2] Lizardo R., Peiniau J., Aumaitre A. Inclusion of sugar-beet pulp and change of protein source in the diet of the weaned piglet and their effects on digestive performance and enzymatic activities. Animal Feed Science and Technology. No 66, 1997, pp. 1-14.

[3] Булавин С.А., Колесников А.С. Безотходная энергосберегающая технология сушки и переработки свекловичного жома (Wasteless energy-saving technology drying and processing of sugar beet pulp). Innovations in agrarian and industrial complex: problems and prospects, No 4 (4), 2014, pp. 3-8. (In Russian).

[4] Магомедов М.Г. Технология получения пасты из сахарной свеклы (The technology of paste from sugar beet obtaining). Proceedings of the Voronezh State University of Engineering Technologies, No 3, 2014, pp. 138-141. (In Russian).

[5] Kühnel S., Schols H. A., Gruppen H. Aiming for the complete utilization of sugar-beet pulp: examination of the effects of mild acid and hydrothermal pretreatment followed by enzymatic digestion. Biotechnology for Biofuels. No 4, 2011.

[6] Patelski P., Berlowska J., Dziugan P. et al. Utilisation of sugar beet bagasse for the biosynthesis of yeast SCP. Journal of Food Engineering. No 167, 2015, pp. 32-37.

[7] Leijdekkers A.G.M., Bink J.P.M., Geutjes S., Schols H.A., Gruppen H. Enzymatic saccharification of sugar beet pulp for the production of galacturonic acid and arabinose; a study on the impact of the formation of recalcitrant oligosaccharides. Bioresource Technology. No 128, 2013, pp. 518-525.

[8] Донченко Л.В., Фирсов Г.Г. Пектин: основные свойства, производство и применение. М.: ДеЛи принт, 2007. 276 с. (Donchenko L.V., Firsov G.G. Pectin: main properties, production and use. M.: DeLee print, 2007. 276 p.) (In Russian).

[9] Agata Z., Marie-Helene B., Hanna K., Johanna B., Jean-Francois T., Estelle B. Extraction of Green Labeled Pectins and Pectic Oligosaccharides from Plant Byproducts. Agricultural and food chemistry. No 56, 2008, pp. 8926-8935.

[10]Колесников А.С. Совершенствование технологической схемы и технологических средств для получения кормовых дрожжей из свекловичного жома (Technological scheme receiving of fodder yeast from sugar beet pulp). Innovations in agrarian and industrial complex: problems and prospects, No 1(5), 2015, pp. 3-10. (In Russian).

[11] Ghanem A., Lemenand T., Della Valle D., Peerhossaini H. Static Mixers: Mechanisms, Applications, and Characterization Methods - A Review. Chemical Engineering Research and Design. Vol. 92, No 2, 2014, pp. 205-228.

[12] Chausov F.F. Domestic static mixers for continuous blending of fluids. Chemical and Petroleum Engineering. Vol. 45, No 3-4, 2009, pp 126-132.

[13] Khurmi R.S. A textbook of engineering mechanics. Ram Nagar, New Delhi: Chand \& Co Ltd., 2008. $778 \mathrm{p}$.

[14]Hunt B. Fluid mechanics for civil engineers. New Zealand: Department of Civil Engineering University Of Canterbury Christchurch, 1995. 366 p.

[15] Encyclopedia of Microfluidics and Nanofluidics. Dongqing Li Ed. Springer, 2008. 2242 p. 